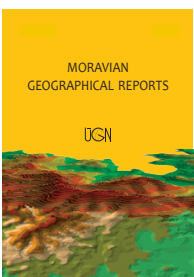

MORAVIAN GEOGRAPHICAL REPORTS

\title{
Bus and train connections between towns in Lower Silesia under different operational models: Competition or complementarity?
}

\author{
Mateusz SMOLARSKI ${ }^{\text {* }}$, Wojciech JURKOWSKI ${ }^{\text {a }}$, Andrzej RACZYK ${ }^{\text {a }}$
}

\begin{abstract}
Relationships between the activities of bus carriers and rail passenger traffic (and the railway offer) are examined in this article. The study was carried out in peripheral areas located at the Polish and Czech borderlands in Lower Silesia province. High quality rail transport generally increases the demand for transport services. Therefore, the proper development of transport offer plays a key role in the functioning of public transport systems, the backbone of which is rail transport. The study also shows that under conditions of transport market deregulation, bus carriers have developed a competitive network which is not complementary to rail transport. As a consequence, the deregulation of the transport market has increased the risk of transport exclusion.
\end{abstract}

Key words: public transport systems; peripheral areas; integrated transport systems; rail transport; bus transport; transport exclusion; Poland

Article history: Received 27 April 2018, Accepted 10 December 2018, Published 31 March 2019

\section{Introduction}

The market for Polish transport services undergoes frequent changes. The transformation that took place in Poland in the 1990s and, after Poland's accession to the European Union, primarily affected rail and bus transport (Taylor, 1998, 2004; Cantos et al., 2012; Połom and Goliszek, 2017). In both organisational and spatial dimensions, such changes generally limited the availability of public transport to residents (Taylor and Ciechański, 2017).

The public bus transport market experienced strong fragmentation. It was connected with the functioning of two categories of transport companies: private independent carriers, and companies created from the previouslyoperated state-owned enterprises (Ciechański and Taylor, 2017). The number of carriers and their transport offer were subject to continuous change and the spatial scope of their activity was mostly subordinated to freemarket principles. Consequently, they operated mostly (or only) on the most profitable routes ${ }^{1}$. Many of them were significant competitors to rail transport (Smolarski and Suszczewicz, 2017).

Polish rail transport also experienced significant organisational changes. One of the manifestations of these changes was the appearance of self-governing companies, including the Lower Silesian Railways. This can be seen as the drive to create more efficient transportation systems, which was particularly intense at the turn of $20^{\text {th }}$ and $21^{\text {st }}$ centuries (Taylor, 2006; Taylor and Ciechański, 2006; Taylor and Ciechański, 2010, 2011). In the Lower Silesia province there were also significant changes in the volume of railway transport operation (mainly resulting from reductions of railway lines and suspension of passenger traffic) and bus services (liquidation of state-owned companies called Państwowa Komunikacja Samochodowa (hereinafter PKS).

Such changes mostly affected the rail company $\mathrm{PKP}^{2}$. They were connected with relatively lower financial expenditures on railway infrastructure compared to Western European

\footnotetext{
${ }^{a}$ Department of Spatial Management, Institute of Geography and Regional Development, Faculty of Earth Sciences and Environmental Management, University of Wrocław, Wrocław, Poland (*corresponding author: M. Smolarski, e-mail: mateusz.smolarski@gmail.com)
}

\footnotetext{
${ }^{1}$ An example is the local transport in Wałbrzych (the Lower Silesia province) where bus transport operating on free market principles is often based on microbus fleets (Smolarski and Jurkowski, 2016).

${ }^{2}$ PKP: Polskie Koleje Państwowe S.A. - Polish State Railways which is the dominant railway operator in Poland.
} 
countries (Nash, 2010). Consequently, a series of railway lines were closed, many of which were of significant importance to local communities and enabled their access to the public transportation system. Studies on the social consequences of the suspension of passenger traffic were carried out in many countries, including Poland (Taylor, 2006), France (Thevinin et al., 2016) and Great Britain (Patmore, 1962).

Regional and local public transport is based on rail and bus connections. Their appropriate coordination and the creation of an integrated public transportation system connecting two or more means of transport within one journey, are of key importance (Ciechański, 2006; Štastná et al., 2012; Štastná et al., 2015; Chowdhury and Ceder, 2016; Chowdhury et al., 2018; Jurkowski, 2018). Relations between rail and bus transport on specific routes may contribute to changes in public transport accessibility (Guzik, 2016; Kowalczyk, 2018). This is particularly important under conditions of deregulation and the lack of coordination of the transportation system in peripheral areas of provinces threatened with transport exclusion ${ }^{3}$. Mees (2010) also emphasised the issue of coordination, referring to the network effect in planning public transport. The system should rely on various means of transport.

In this article, we aim to identify the associations between the activity of bus carriers and rail passenger traffic. It should then be possible to answer questions of whether bus and rail carriers compete with each other under the conditions of deregulation and the lack of coordination, or whether they complement their transport offers; in addition, responses to how their relations change over time depending on the transport offer and the demand for transport services are illustrated. Moreover, the article examines whether, and to what extent, the transportation system formed may affect transport exclusion. The Polish transportation system is based on rail transport, which is organised by central authorities (fast and international connections) or voivodships (regional transport). On the other hand, bus transport is characterised by a lack of coordination. Following the reorganisation of the Polish bus transport market, state enterprises (PKS) were transformed and divided (some of them were liquidated or privatised: see Taylor and Ciechański,2018). In addition to these types of companies, there are many private enterprises that create some transport offer mainly due to economic calculations.

\section{Theoretical basis}

Most authors either treat the public transportation system jointly (Štastná and Vaishar, 2017; Štastná et al., 2015) or focus on only one means of transport, e.g. in Cyprus (Kepaptsoglu, 2017). Others compare various rail systems (Fraszczyk et al., 2016). There are relatively few studies concerning relations between various means of public transport, particularly in the context of mutual competition between bus and rail carriers. For example, Ben-Akiva and Morikawa (2002) indicate that a high-quality offer plays the key role, and the selection of the means of transport (a bus or a train) is thus of secondary importance.

It must be noted that in many countries (in Western Europe in particular), there is often no basis for studying relations between rail and bus carriers as they operate based on the principle of complementarity and, in fact, fulfil separate functions. Therefore, the dependencies between rail and bus transport networks were mostly studied in the context of so-called feeder lines, e.g. using optimisation models which determine perfect access to railway lines (Wirasinghe, 1980; Kuah and Perl, 1988; Chien and Schonfeld, 1998; Jurkowski and Smolarski, 2017a).

Another problem involves imperfections of public transport in rural areas. Petersen (2016) has described this problem in Britain, where they are referred to as 'patchy' due to low frequency and limited running time (e.g. no public transport in the evenings and at weekends). Rural areas can be characterised by low population density and, consequently, low passenger demand (Nielsen and Lange, 2007). One of the few studies about the relationships of rail and bus networks in Central and Eastern Europe is an analysis of the coordination of rail routes, and the introduction of integrated systems is suggested to be the most effective solution (Kudlać et al., 2017).

It must be noted, however, that there are significant differences between the organisation of public transport in metropolitan, urban, rural and peripheral areas ${ }^{4}$. Malikova (2013) considers the transport accessibility of cities as one of the indicators of marginalisation and peripheralisation in Slovakia and the Czech Republic. Boruta and Ivan (2010), however, have used the example of the Jeseník region in the Czech Republic to show that a public transportation system including road and rail connections may be effective, even in rural areas which are relatively economically under-developed (Ivan and Boruta, 2010). In contrast, Jaroš (2017, p. 258) stresses that "high area mobility is typical of core areas, while low area mobility is usual in rural or peripheral areas". Differences in the organisation of the system are also visible in urban centres of various sizes. For example, in cities with less than 100,000 inhabitants, a bus-line system is unnecessary. In turn, in large agglomerations, it works perfectly, allowing one to bypass the city centre when travelling (Nielsen and Lange, 2007).

Data on passenger flows may help in determining to what extent a city is connected with its region. While towns usually generate local traffic, cities and agglomerations are more fequently connected with more distant areas. Kraft et al. (2011) studied the influence of urban centres in the Czech Republic (the capital cities of Czech regions) based on vehicle traffic flows. They identified differences in the transport connections of particular cities based on access to work and vehicle transport flows. Halas et al. (2010) conducted similar studies related to the access to work in Prague and Brno.

Peripheral areas are characterised by specific public transport conditions, such as departure times, low frequency of departures, lack of direct connections and the lack of coordinated interchange systems (Petersen, 2012, 2016). Even areas with seemingly high transport accessibility potential, for example those located close to urban agglomerations, are often referred to as "car dependent suburban areas" (Hickman and Banister, 2014, p. 141). The researchers indicate that in this case, it is necessary to use local rail and bus systems more widely. Štastná et al.

\footnotetext{
${ }^{3}$ Effective public transport connections can act against the marginalisation of peripheral, problematic areas. This dependence has been identified on the Czech-Slovakian-Austrian border by Vaishar (2008).

${ }^{4}$ Nash (1982) has distinguished rural, interurban and urban transport.
} 
(2015) also stress the role of transport organisation in peripheral areas and point out that the authorities should take major steps in this regard in urban and metropolitan areas. Some European countries have introduced para-public transportation systems, such as 'Anruf taxi' in Germany and 'Publicar' in Switzerland (Velaga et al., 2012), but they can also be minibuses, taxis, or school buses (Nielesen and Lange, 2007).

Problems related to the development of transportation systems are observed as particularly acute in post-socialist European countries, in which economic transformation caused huge changes after 1990 and in many cases led to chaos in the functioning of transport. Public transport networks were reduced and many local railway lines were suspended in Poland and the Czech Republic. Taczanowski (2012) has identified significant differences in the number of local rail routes which were closed down in Poland and the Czech Republic. He indicates that $90 \%$ of third category railway lines and $44 \%$ of second category railway lines were closed down in Poland between 1989 and 2011, and 14\% of local routes were suspended in the Czech Republic. This process was particularly intense in the Lower Silesia region (Smolarski and Raczyk, 2017).

Rail infrastructure can be considered as the backbone of public transport. Santos et al. (2010) also stress the role of transport infrastructure, particularly in rural areas. Tomeš et al. (2014, p. 275) note that the "competitiveness of railway transport is crucially dependent on the quality and capacity of the infrastructure". Wegener et al. (2005, p. 27) stress that "the relationship between transport infrastructure and economic development has become more complex than ever". They also state that the construction of a new railway line between peripheral and central regions may improve the economic situation of the peripheries (Wegener et al., 2005, p. 28). A complex upgrading of existing routes and the introduction of attractive timetables may also improve transport accessibility. For example, Jurkowski and Smolarski (2017b) note that the transport offer on the Wrocław-Warsaw route significantly improved after one of its sections had been upgraded.

The creation of a reliable and simple transportation system could be the solution. This would involve developing co-ordinated interchange systems in local interchange nodes in peripheral areas. According to Buehler and Pucher (2012), this kind of system exists in Germany. Switzerland deserves special attention as it has one of the highest numbers of public transport journeys per person among European countries (Buehler and Pucher, 2012), and a specific public transportation system in rural areas (Petersen, 2016). The simplicity of the transport system can be considered as a factor encouraging people to use public transport. If the potential passenger is able to understand its operating principles, there is a greater chance that $\mathrm{s}$ / he will become a real passenger. Car users often base their decisions on the choice of individual transport as they are not able to clearly use the public transportation system (Nielsen and Lange, 2007).

The role of integrated systems, understood as a joint rail and bus transport system, is especially important in creating regional transport connections. The first systems of this type were formed in Germany, Switzerland and Austria (Śtastná, 2015). An integrated transportation system helps avoid transport exclusion (Štastná and Vaishar, 2017, p. 112). Moreover, it allows people unable to use road transport to use public transport (Lucas, 2012), for example, children, the elderly and disabled people (Štastná, 2015)

According to Chowdhury and Ceder (2016), integrated transportation systems should be based on five elements of integration: [1] network integration; [2] information integration; [3] integrated timed-transfers (connections, where transfer time is reduced to a minimum ${ }^{5}$ ); [4] fare integration (Sharaby and Shiftan, 2012); and [5] physical integration. The systems should offer the possibility of a smooth journey using various means of transport. In rural areas, transfers are inevitable, therefore the role of connections between various means of transport and interchanges is growing in importance (Nielesen and Lange, 2007).

Studies carried out in the rural areas of England and Wales revealed the problem of transport exclusion of elderly people, with the result that they had difficulty accessing hospitals, clinics, local centres, etc. (Shergold and Parkhurst, 2012). The problem of the negative perception of public transport was identified in rural areas of Scotland - while $50 \%$ of inhabitants of urban areas considered public transport to be a convenient means of transport, this opinion was only shared by $20 \%$ of residents of rural areas (Velaga et al., 2012).

It should be noted, however, that mobility levels are highly dependent on local and national conditions. Buehler (2011) shows that $8 \%$ of journeys in the rural areas of Germany are made by public transport, compared to only $2 \%$ in the United States of America.

The functioning of transport also depends, to a significant extent, on formal principles pursued in particular countries. Deregulation should not be carried out in an uncontrolled and unorganised way, because it can affect the efficiency of the transportation system (Mees, 2010). Knowles and Hall (1992) use the example of Great Britain to assess the deregulation of the public bus transport which was carried out there. On the one hand, it increased the economic effectiveness of transport, but on the other hand, the main bus traffic flows were moved to densely populated areas with the highest transport potential. This creates the risk of insufficient transport services in rural and peripheral areas. The issue of public transport deregulation after 1990 in the countries of central and eastern Europe was the subject of study conducted in Hungary (Nelson et al., 1997). The study on competition in rail transport in the Czech Republic showed a significant complex problem and the lack of unambiguous (only negative or only positive) consequences of the liberalisation of the rail transport market. Tomeš et al. (2014) noted that new carriers most often run on routes with the highest passenger volumes and exclude local and peripheral routes.

With regard to rail transport, Fröidh and Nelldal (2015), using the example of Sweden, show that the deregulation of regional connections led to increased segmentation of passengers into those who paid attention to price (the problem of travel costs) and those who paid attention to time (the problem of travel time). Furthermore, Fröidh and Byström (2013) noticed that deregulation has improved the quality of rail transport services.

\footnotetext{
${ }^{5}$ As Mees (2010, p. 84) points out, obstacles to the creation of integrated transport systems are poorly organised transfers, which require, among other factors, additional costs or significantly longer travel time.
} 


\section{Study areas and methods}

This study was conducted in two sub-regions: Jelenia Góra and Wałbrzych, according to the NUTS 3 classification. The examined areas are considered to be problematic and are thus treated as peripheral in spatial, social, economic and transport terms in both the reference literature (see: Ciok, 1991, 1994; Churski, 2010; Kolejka et al., 2015) and planning documents (e.g. Plan zagospodarowania... 2014; Koncepcja... 2011, p. 172). The eastern and western areas under study are characterised by difficult access to the nearest large urban centres (Stępniak et al., 2013). At the same time, due to their natural sites and tourist attractions (e.g. two national parks), these areas have high potential in terms of tourist movement and the use of public transport. Dickinson and Robbins (2008), among others, indicate the important role of public transport in areas of high tourist potential. The analysed sub-regions are, at the same time, border areas with relatively low transport accessibility to metropolitan centres in Poland and the Czech Republic. A study on inter-municipal rail connections in Polish and Czech border areas showed significant differences between the Polish and Czech rail transportation systems, and indicated that their organisation was worse on the Polish side (Smolarski, 2017).

This study was intended to cover the most peripheral units at the highest risk of transport problems (see Fig. 1). To this end, nine nodes were specified: Wegliniec, Zgorzelec, Lubań, Jelenia Góra, Szklarska Poręba, Wałbrzych, Kłodzko, Międzylesie, Kudowa Zdrój (border towns on the Polish side were also treated as nodes). The basic units of observation were towns and cities located within sections between the aforementioned nodes.

With regard to rail transport, the general number of rail connections and the total number of passengers were examined on sections between the nodes specified above. They were calculated as the sum of passenger volumes at all stations located between the specified nodes. This approach made it possible to analyse particular sections as traffic generators. It took account of the number of passengers getting on at particular stations regardless of their final destination. The study excluded long-distance connections

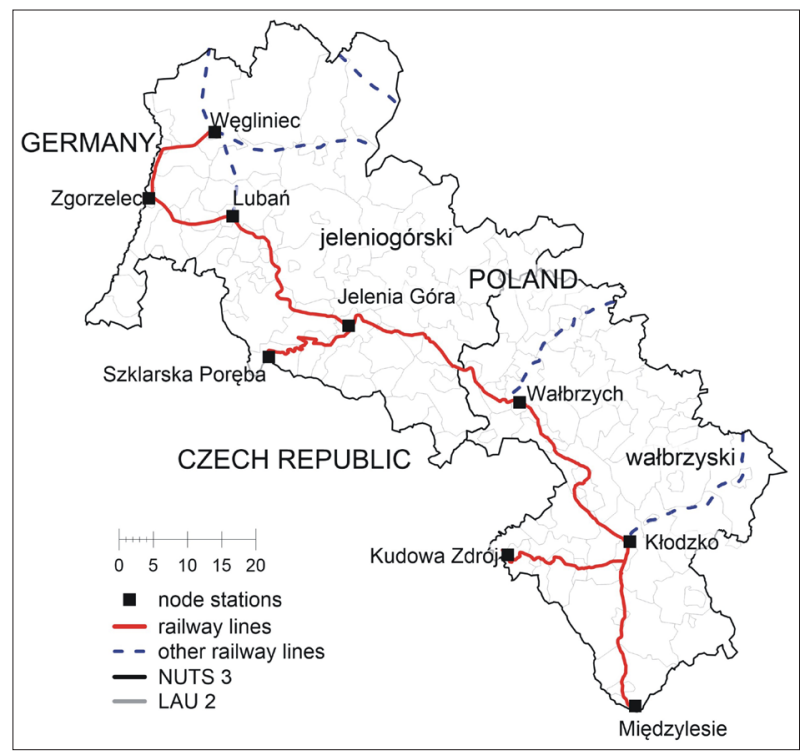

Fig. 1: Research area. Source: authors' elaboration

(reaching beyond the regions) due to the lack of data on this type of connection. It must be stated, however, that these are of little importance for the number of connections and passengers and that they play a marginal role in the formation of local transport connections. Data on rail offers were taken from public train timetables for stations in particular towns and cities available at the website rozklad-pkp.pl.

With regard to bus transport, the study covered all lines connecting specific cities and towns with each other. In this case, connections reaching beyond the region were also excluded from the analysis because they do not affect local transport connections. As it was impossible to receive more detailed information, only the number of connections was taken into account. Data were obtained from the website e-podróżnik. $\mathrm{pl}^{6}$, and the websites of relevant carriers. Every outbound bus connection in the cities and towns studied was classified as one of two types: networked or competing with a rail route, and assigned to one of the organisational forms depending on the carrier type: independent (private enterprises) or PKS (state-owned enterprises) ${ }^{7}$ (Fig. 2).

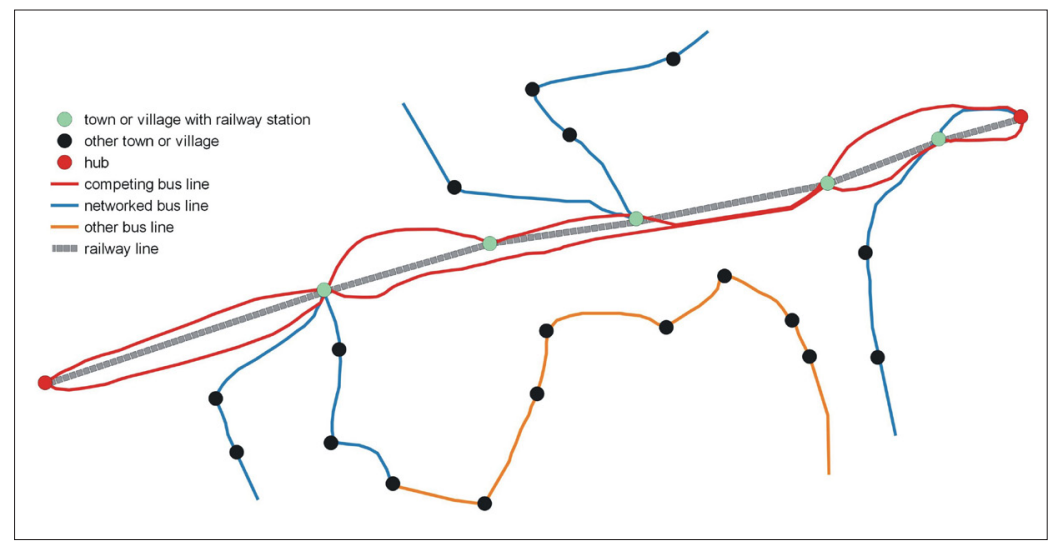

Fig. 2: Competing and networked bus lines (schematic) Source: authors' elaboration

\footnotetext{
${ }^{6}$ Given the lack of public transport coordination in Poland, especially regarding buses, the website is a nationwide database for most bus journeys. In order to improve public transport coordination, a complex search engine for finding public rail and bus transport connections should be created, e.g. similar to the Czech website: jizdnirady.idnes.cz

7 State-owned bus carriers are enterprises formed after the transformation of the enterprise Państwowa Komunikacja Samochodowa (PKS). At present, they are the property of local governments, worker-owned companies and state-owned companies (Taylor and Ciechański, 2017, p. 115).
} 
A bus connection was considered as competing with a rail route when most of its route covered the same cities and towns as the rail transport. In other words, the course of the bus route was more or less parallel to a train route. A bus connection was considered networked when its route was perpendicular to a rail route on a given section of a railway line and could potentially function as the so-called feeder bus, transporting passengers to nodes from areas having no railway network.

While the basic reference units were cities and towns, a higher level of aggregation was used for the purpose of analysing the results obtained. The study involved 50 cities and towns located on eight inter-node sections. They were the basis for data analysis. This research approach was used because analysis of single towns and cities would have made it difficult to obtain more general patterns due to their specific and unique conditions. In many cases, such general patterns can only be identified at a higher level of aggregation (inter-node sections).

This is the approach that is usually applied in the reference literature. While studying the metro system, Derrible and Kennedy (2010, p. 278) stated that "a metro node is not a node if it does not offer a transfer". It must be remembered, however, that the possibility of an interchange is necessary for a given station to be considered a node (Derrible and Kennedy, 2010, p. 278). When studying the quality of rail and air connections in Eastern Europe, Janić (1997) also referred to the largest cities (nodes) without analysing particular towns between the nodes. Peeters et al. (1998, p. 369) draw attention to the issues of social and economic activities which are most often concentrated in the largest transport nodes. They state that "the main nodes of the transportation network are likely to be the local points of an economic geography in which human activities become ... footloose".

The study was conducted using the following indicators of demand, supply and assessment of the effectiveness of rail and public bus transport:

1. the size and market share of private and state-owned bus operators;

2. the number and market share of networked and competing journeys;

3. weekday-weekend disparity (differences between the number of weekend and weekday connections $)^{8}$;

4. the number of bus and rail connections; and

5. the efficiency of rail connections in terms of the detour index (Śleszyński, 2014, pp. 190-191).

Data concerning the number of passengers using passenger transport were taken from weekly measurements of passenger volumes conducted on trains in the period from 3 to 9 April, 2017. The selected period was characterised by normal traffic intensity close to the yearly average. It included typical weekdays and weekend days with no (statutory) bank or public holidays. Moreover, there were no complications on the road and rail networks at that time which could interfere with bus and rail traffic. Data about the number of rail and bus connections concern the same time period.

\section{Results and discussion}

Two public transport companies operate in the study area: Koleje Dolnośląskie S.A. and Przewozy Regionalne S.A. Koleje Dolnośląskie is managed by regional authorities (the Marshall's Office of Lower Silesia Province). Przewozy Regionalne operates nationwide so its activity has not been studied. Koleje Dolnośląskie carries out $89 \%$ of rail transport in the Lower Silesia province ${ }^{9}$. The analysis allows the issues connected with rail transport in the region to be captured with high precision. It must be mentioned, however, that Koleje Dolnośląskie provides services for some $36 \%$ of all passengers (including those travelling by other means of transport) in the region.

As far as Polish bus enterprises are concerned, the PKS state-owned companies operated in five cities in the area under study (2017): Jelenia Góra, Kłodzko, Lubań, Bolesławiec and Kamienna Góra. In recent years, three companies have been closed down: in Świdnica, Zgorzelec and Wałbrzych.

\subsection{Rail offer and generators of passenger traffic}

The study results were analysed with respect to rail transport and bus carriers. A general assessment of the transport offer was made using a synthetic indicator because studying the actual number of connections or travel time could have been unreliable since it is difficult to state which factor is the decisive one.

The synthetic indicator ${ }^{10}$ included the most important components of the transport offer influencing passenger behaviour as most often described in the literature (van Lierop et al., 2017):

a. the number of rail connections: this indicator refers to Chakour and Eluru (2016) who noted that public transport stops offering a greater number of connections generate higher passenger volumes;

b. time effectiveness of rail transport in comparison to individual transport on a given route (the so-called detour index): Rodrigue et al. (2009) and Mouwen (2015) note that travel time

c. speed - travel time and travel speed are as important as frequency of departure and the quality of timetables (Stuart et al., 2000); and

d. intervals (meaning the time between departures) Weinstein (2000) and Mouwen (2015).

The study results show that the highest value of the synthetic indicator was reported on the Wałbrzych - Jelenia Góra section, which had the highest number of pairs of connections per day (13) and trains were much faster than road transport. A high indicator value was also obtained on the Wegliniec-Zgorzelec section. Despite a significantly lower number of connections per day (8), travel effectiveness was of high importance. The lowest values were obtained on the Szklarska Poręba-Jelenia Góra and Kłodzko-Kudowa sections. In the first case, the number of pairs of connections was low (5), resulting in extended intervals between departures. In the second case, a slightly higher number of connections (7) was accompanied by low speed $\left(33 \mathrm{~km} \cdot \mathrm{h}^{-1}\right.$ on average), which resulted in almost doubling train travel time compared to car transport.

\footnotetext{
${ }^{8}$ A high-quality weekend and weekday public transport offer is an element of daily routine travels, which are a significant aspect of life (Nutley, 2003).

${ }^{9}$ Source: Office of Rail Transport, 2017.

${ }^{10}$ After the normalisation process, the mean value of the characteristic was determined as a synthetic indicator.
} 
It was important to study correlations between the transport offer and the number of passengers, i.e. the supply-demand relationships in rail transport. Other studies on this type of transport offer (e.g. van Lierop et al., 2017) show that they significantly affect passenger volumes on particular lines, indicating that this factor is important particularly in peripheral areas, where uniform rail quality standards occur less often than within an agglomeration. In order to eliminate the factor of different passenger volumes in particular units, the index of the mean rail passenger volume over 24 hours per station of a given line has been incorporated in this study. (This indicator was the quotient of the total passenger volume getting on at all the stations of a given line, as well as the total number of stations on this line: see Fig. 3). The study shows significant differences in passenger volumes on particular lines - it was almost three times higher on the Wałbrzych-Jelenia Góra section than on the Kłodzko-Kudowa Zdrój line. This confirms that a good transport offer generates high passenger volumes and a low-quality transport offer adversely affects the number of passengers (Fig. 3).

\subsection{Bus offer}

The greatest number of bus connections is offered on railway routes with a low-quality transport offer and low passenger volumes (see Fig. 4). Moreover, a greater number of rail passengers is accompanied by a smaller number of bus connections in these areas. In extreme cases (e.g. on the Wegliniec-Zgorzelec section), there are no bus carriers due to very high rail passenger volumes.

\subsection{Competing and networked journeys and types of carriers}

Bus carrier routes constitute a significant problem for the functioning of local and regional transportation systems. In general, even $77 \%$ of all the examined bus lines were competing with train routes, meaning that both means of transport compete with rather than complement one another (Tab. 1). It must be stressed that the number of competing connections was the highest on two of the least-used railway lines at $95 \%$ (Kłodzko-Kudowa) and 100\% (Jelenia GóraSzklarska Poręba). If the quality of railway offer is low, bus carriers focus almost completely on taking over rail passengers along those routes. If, however, the rail offer is more attractive, the share of networked bus connections is increased. The lowest share of competing connections was reported on the Jelenia Góra-Lubań line.

Some relationships can also be observed in the market share of private bus operators. Generally, it was lower along well-functioning railway lines with high demand, e.g. no private carrier operated on the Kłodzko-Międzylesie section and the share of private carriers amounted to slightly more than $25 \%$ on the Wałbrzych-Jelenia Góra section. At the

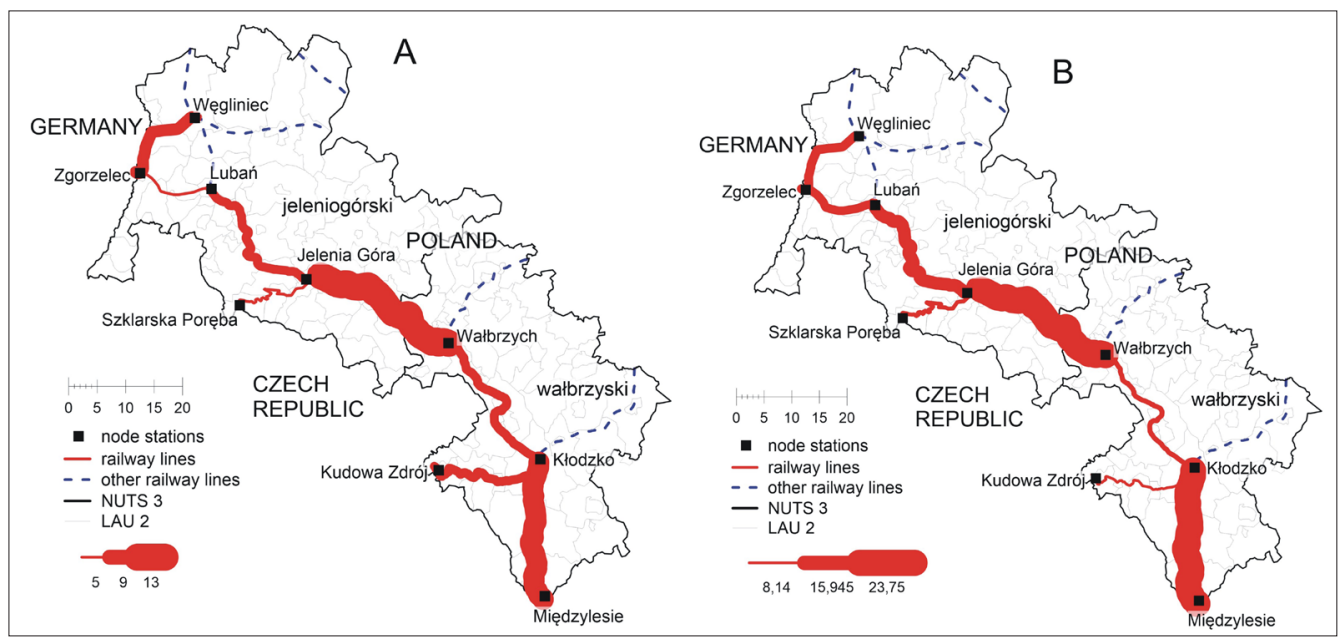

Fig. 3: The number of rail connections (A) and the indicator of the mean volume of passengers entering trains per station (B) on sections between transport nodes in the study area. Source: author's elaboration

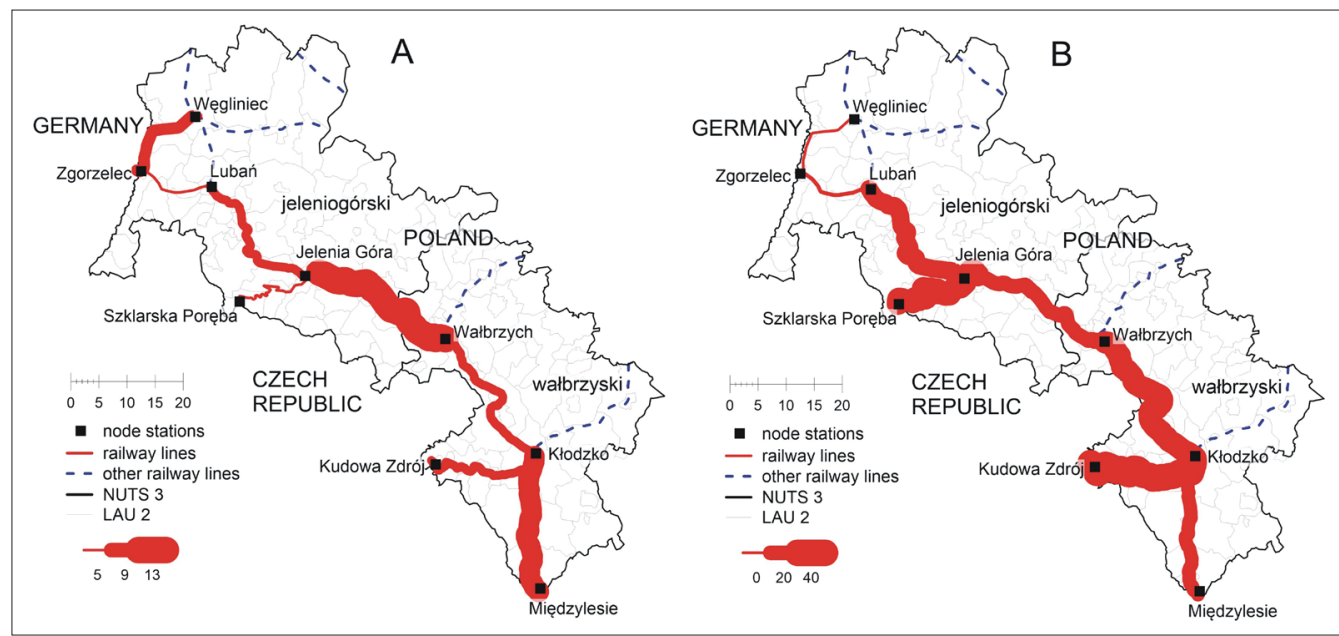

Fig. 4: The number of rail (A) and bus (B) connections on sections between transport nodes in the study area Source: authors' elaboration 


\begin{tabular}{lcc}
\hline Line & $\begin{array}{c}\text { Competing } \\
\text { courses (\%) }\end{array}$ & $\begin{array}{c}\text { Networked } \\
\text { courses (\%) }\end{array}$ \\
\hline Węgliniec-Zgorzelec & \multicolumn{2}{c}{ no bus carriers } \\
Zgorzelec-Lubań & 66 & 33 \\
Lubań-Jelenia Góra & 56 & 44 \\
Jelenia Góra-Szklarska Poręba & 100 & 0 \\
Jelenia Góra-Wałbrzych & 77 & 23 \\
Wałbrzych-Kłodzko & 75 & 25 \\
Kłodzko-Międzylesie & 73 & 27 \\
Kłodzko-Kudowa Zdrój & 95 & 0 \\
Average & $\mathbf{7 7}$ & $\mathbf{2 2}$ \\
\hline
\end{tabular}

Tab. 1: Competing lines and networked lines Source: authors' elaboration

same time, the share was almost 50\% along railway lines with a low-quality offer (e.g. Jelenia Góra-Szklarska Poreba). This indicates that the network of connections developed by public bus carriers was more in line with the provision of an integrated transportation system. Private carriers mostly responded to existing demand rather than to the needs of local communities at risk of transport exclusion. In general, this may also result from the smaller number of weekend bus connections by which private carriers gain greater market share even when providing services on one route only (see Tab. 2).

\subsection{Weekday - weekend differences in bus transport}

A characteristic feature of the area under study is the weekday-weekend difference in bus connections (Tab. 3). The average number of Saturday journeys was $32 \%$ of weekday journeys, and the average number of Sunday journeys was less than $17 \%$ of weekday journeys. At the same time, some lines had no weekend offer (e.g. the Zgorzelec-Lubań and Kłodzko-Międzylesie lines). Moreover, there was a very low share of Sunday journeys on the Lubań-Jelenia Góra and Jelenia Góra-Wałbrzych routes. The lowest decrease in the number of weekend connections amounting to some 4048\% was reported on the Jelenia Góra-Szklarska Poręba, Kłodzko-Wałbrzych and Kłodzko-Kudowa sections. Such a significant reduction of the bus offer at weekends, even if this is not a continuous phenomenon, may lead to periodical transport exclusion.

When analysing the structure of carriers on Saturdays and Sundays, it is noticeable that private carriers operated on all sections, thus clearly increasing their share of the transport market. This is due to a smaller network of connections provided by private carriers, who mostly operate on routes with the highest demand and competing with rail routes which also need to provide services at weekends. Moreover, PKS carriers also provide their services on many networked routes characterised by low weekend demand. This leads to a reduction of PKS's share of weekend transport and an increased share for private carriers, which additionally highlights the fact that both carriers have different ideas on how they should function under conditions of transport system deregulation.

The indicators selected for the analysis characterising the functioning of transportation systems are modifications of the transport accessibility test methods. There are four basic components that make up the availability (Geurs and van Wee, 2004): land-use, transport, time and individual use. The first two are crucial for public transport research (Komornicki et al., 2010, p. 21). The transport component is the same as travel time, while the use of space is the distribution of needs and opportunities (Rosik, 2012). The transport component can be considered as a transportation system (Komornicki et al., 2010, p. 34). Public transport research should concern various transport branches (Komornicki et al., 2018). Other accessibility indicators may include: distance in a straight line, distance on the communication network, driving time, travel costs or the quality of public transport (Curtis and Scheurer, 2010).

\section{Conclusions and recommendations}

This study shows that a good railway offer almost always indicates a relationship with rail transport services. It does not unambiguously determine to what extent the transport offer was the main reason for the increase in this demand, however, but it underlines its importance in shaping public transportation systems.

The study made it possible to identify very detailed associations between the demand for rail transport and bus offers. On railway lines with an insufficient transport offer and the resulting low demand for rail transport services, bus carriers developed mainly a network of connections which were competitive rather than complementary to the rail transport. This regularity was observed mostly among private carriers operating under market conditions and aiming at profit maximisation. Some measures taken by public bus transport (PKS) conform to the requirements of the integrated approach.

\begin{tabular}{lcccc}
\hline Line & $\begin{array}{c}\text { Post PKS carriers } \\
(\%)\end{array}$ & $\begin{array}{c}\text { Private carriers } \\
(\%)\end{array}$ & $\begin{array}{c}\text { Post PKS carriers } \\
\text { weekend (\%) }\end{array}$ & $\begin{array}{c}\text { Private carriers } \\
\text { weekend (\%) }\end{array}$ \\
\hline Węgliniec-Zgorzelec & \multicolumn{2}{c}{ no bus carriers } \\
Zgorzelec-Lubań & 100 & 0 & 100 & 0 \\
Lubań-Jelenia Góra & 55 & 45 & 40 & 60 \\
Jelenia Góra-Szklarska Poręba & 43 & 57 & 37 & 63 \\
Jelenia Góra-Wałbrzych & 72 & 28 & 50 & 50 \\
Wałbrzych-Kłodzko & 42 & 58 & 48 & 52 \\
Kłodzko-Międzylesie & 100 & 0 & 100 & 0 \\
Kłodzko-Kudowa Zdrój & 78 & 22 & 73 & 27 \\
Average & $\mathbf{7 0}$ & $\mathbf{3 0}$ & $\mathbf{6 4}$ & $\mathbf{3 6}$ \\
\hline
\end{tabular}

Tab. 2: The market share of bus carriers on weekdays and weekend days

Source: author's elaboration 


\begin{tabular}{lcc}
\hline Line & $\begin{array}{c}\text { Saturday } \\
\text { irregularity } \\
(\%)\end{array}$ & $\begin{array}{c}\text { Sunday } \\
\text { irregulatity } \\
(\%)\end{array}$ \\
\hline Węgliniec-Zgorzelec & - & - \\
Zgorzelec-Lubań & 0 & 0 \\
Lubań-Jelenia Góra & 21.7 & 8.4 \\
Jelenia Góra-Szklarska Poręba & 71.7 & 19.8 \\
Jelenia Góra-Wałbrzych & 27.4 & 7.1 \\
Wałbrzych-Kłodzko & 48.6 & 31.2 \\
Kłodzko-Międzylesie & 3.5 & 3.5 \\
Kłodzko-Kudowa Zdrój & 49.4 & 47.0 \\
Average & $\mathbf{3 1 . 7}$ & $\mathbf{1 6 . 7}$ \\
\hline
\end{tabular}

Tab. 3: Weekday-weekend differences in bus transport. Source: authors' elaboration

The study indicates that under conditions of deregulation and lack of coordination of transportation system development, most bus connections duplicate the railway system. This means that there are activities related to competition between both modes of transport (rather than their mutual complementarity). If transportation systems in the area under study are not based on integrated public transport, many towns will face the risk of transport exclusion. This will increase the peripheral character of the area and reduce its competitiveness, which may adversely affect the pace of its social and economic development. The scale of this phenomenon requires separate studies of coordination of public transportation system to be conducted.

Analysis of the weekday-weekend differences in bus and rail offers shows that rail connections are relatively similar throughout the week. There are definitely more differences in bus transport - on all the examined lines, the number of bus connections at weekends amounted to less than 50\% of bus connections on weekdays. Therefore, basing the regional transportation system only on private bus transport can contribute to transport exclusion of local residents (Jaroš, 2017) - if not in a continuous mode, then certainly in a periodical dimension (non-working days, evenings, etc.). This indirectly indicates that from the point of view of the connections stability, rail transport should be the starting point for shaping a regional communication system.

With respect to the lack of a coordinated transport policy and the fact that bus transport is mostly based on market principles, there is a risk that bus carriers will further reduce their services at weekends (the so-called 'weekend transport exclusion' - as a derivative of 'transport related social exclusion': Jaroš, 2017). The general solution to this problem might be the development of a transportation system based on rail transport. Weekend bus transport can be based on feeder line systems or be an element of a flexible transportation system. This requires the creation and implementation of a supra-local, integrated public transport policy taking transport exclusion into account.

\section{References:}

BEN-AKIVA, M., MORIKAWA, T. (2002): Comparing ridership attraction of rail and bus. Transport Policy, 9(2): 107-116.

BORUTA, T., IVAN, I. (2010): Public transport in rural areas of the Czech Republic - case study of the Jeseník region. Moravian Geographical Reports, 18(2): 9-22.
BUEHLER, R. (2011): Determinants of transport mode choice: a comparison of Germany and the USA. Journal of Transport Geography, 19(4): 644-657.

BUEHLER, R., PUCHER, J. (2012: Demand for public transport in Germany and the USA: an analysis of rider characteristics. Transport Reviews, 32(5): 541-567.

CANTOS, P., PASTOR, J. P., SERRANO, L. (2012): Evaluating European railway deregulation using different approaches. Transport Policy, 24: 67-72.

CIECHAŃSKI, A. (2006): Integracja kolei z innymi środkami publicznego transportu pasażerskiego. Doświadczenia polskie a krajów ościennych. Prace Komisji Geografii Komunikacji PTG, 12: 113-135.

CHIEN, S. SCHONFELD, P. (1998): Joint optimization of a rail transit line and its feeder bus system. Journal of Advanced Transportation, 32(3): 253-284.

CHOWDHURY, S., CEDER, A. A. (2016): Users willingness to ride an integrated public-transport service: A literature review. Transport Policy, 48: 183-195.

CHOWDHURY, S., HADAS, Y., GONZALES, V. A., SCHOT, B. (2018): Public transport users' and policy makers' perceptions of integrated public transport systems. Transport Policy, 61: 75-83.

CHURSKI, P. (2010): Problem areas in Polish regional policy. Moravian Geographical Reports, 18(2): 23-35.

CIOK, S. (1991): Sudety - obszar problemowy. Wydawnictwo Uniwersytetu Wrocławskiego.

CIOK, S. (1994): Wybrane obszary problemowe Polski południowo-zachodniej. Wydawnictwo Uniwersytetu Wrocławskiego.

CURTIS, C., SCHEURER, J. (2010): Planning for sustainable accessibility: Developing tools to aid discussion and decision-making. Progress in Planning, 72: 53-106.

DERRIBLE, S., KENNEDY, C. (2010): Characterizing metro networks: state, form and structure. Transportation, 37: 275-297.

DICKINSON, J. E., ROBBINS, D. (2008): Representations of tourism transport problems in a rural destination. Tourism Management, 29(6): 1110-1121.

FRASZCZYK, A., LAMB, T., MARINOV, M. (2017): Are railways really that bad? An evaluation of rail systems performance in Europe with a focus on passenger rail. Journal of Transport Geography, 94: 573-591.

FRÖIDH, O, BYSTRÖM, C. (2013): Competition on the tracks - Passengers' response to deregulation of interregional rail services. Transportation Research, Part A: Policy and Practice, 56: 1-10.

FRÖIDH, O., NELLDAL, B. L. (2015): The impact of market opening on the supply of interregional train services. Journal of Transport Geography, 46:189-200.

GEURS, K. T., VAN WEE, B. (2004): Accessibility evaluation of land-use and transport strategies: review and research directions. Journal of Transport Geography, 12: $127-140$.

GUZIK, R. (2016): Transport publiczny a dostępność na obszarach wiejskich Szwajcarii. Prace Komisji Geografii Komunikacji PTG, 19(4): 49-61.

HALÁS, M., KLADIVO, P., ŠIMÁČEK, P., MINTALOVÁ, T. (2010): Delimitation of micro-regions in the Czech 
Republic by nodal relations. Moravian Geographical Reports, 18(2): 16-22.

HICKMAN, R., BANISTER, D. (2014): Affluent rurality and car dependence (Oxfordshire), Transport, Climate Change and the City, Routledge, Abingdon.

IVAN, I., BORUTA, T. (2010): Quantitative and qualitative evaluation of public transport supply in rural regions. Case study of Jeseník region. Europa XXI, 21: 31-45.

JAROŠ, V. (2017): Social and transport exclusion. Geographia Polonica, 90(3): 247-263.

JURKOWSKI, W., SMOLARSKI, M. (2017a): Multimodalne rozwiązania $\mathrm{w}$ transporcie zbiorowym na przykładzie linii dowozowych we Wrocławiu. Prace Komisji Geografii Komunikacji PTG, 20(4): 51-61.

JURKOWSKI, W., SMOLARSKI, M. (2017b): Proteza koniecpolska jako stymulanta rozwoju transportu kolejowego. Przegląd Komunikacyjny, 4: 20-24.

JURKOWSKI, W. (2018): Integracja głównych dworców autobusowych i kolejowych w miastach wojewódzkich w Polsce. Przegląd Komunikacyjny, 73(5): 22-26.

KEPAPTSOGLOU, K., STATHOPOULOS, A. KARLAFTIS, M. G. (2017): Ridership estimation of a new LRT system: Direct demand model Approach. Journal of Transport Geography, 58: 146-156.

KNOWLES, R., HAIL, D. (1998): Transport deregulation and privatization. In: Hoyle, B., Knowles, R. [eds.]: Modern Transport Geography. Chichester, John Wiley\&Sons

KOLEJKA, J., ŻYSZKOWSKA, W., BATELKOVÁ, K. CIOK, S., DOŁZBŁASZ, S., KIRCHNER, K., KREJČÍ, T., RACZYK, A., SPALLEK, W., ZAPLETALOVÁ, J. (2015): Permeability of Czech-Polish border using by selected criteria; Geographia Technica, 10(1): 51-65.

KOMORNICKI, T., ŚLESZYŃSKI, P., ROSIK, P., POMIANOWSKI, P. (2009): Spatial accessibility as the basis for shaping the Polish transport policy KPZK PAN Bulletin 241: Dostepność przestrzenna jako przesłanka kształtowania polskiej polityki transportowej. Biuletyn KPZK PAN 241.

KOMORNICKI, T., ROSIK, P., STĘPNIAK, M., ŚLESZYŃSKI, P., GOLISZEK, S., POMIANOWSKI, W., KOWALCZYK, K. (2018): Evolution and monitoring of changes in the transport accessibility in Poland, using the spatial indicator WMDT, IGiPZ, PAN, MR. Warsaw. Ewaluacja i monitoring zmian dostepności transportowej w Polsce z wykorzystaniem wskaźnika WMDT, IGiPZ, PAN, MR, Warszawa.

KONCEPCJA PRZESTRZENNEGO ZAGOSPODAROWANIA KRAJU 2030 (2011): Ministerstwo Rozwoju Regionalnego.

KOWALCZYK, K. (2018): Typologia multimodalnego potencjału linii kolejowych zlokalizowanych w strefach podmiejskich najwieksszych polskich aglomeracji. Prace Komisji Geografii Komunikacji PTG, 21(1): 17-33.

KRAFT, S., HALAS, M.,VANČURA, M. (2014): The delimitation of urban hinterlands based on transport flows: a case study of regional capitals in the Czech Republic. Moravian Geographical Reports, 22(1): 24-32.

KUAH, G. K., PERL, J. (1988): Optimization of feeder bus routes and bus-stop spacing. Journal of Transportation Engineering, 114(3): 341-354
LIEROP, V. D., BAGAMI, M. G., EL-GENEIDY, A. M. (2017): What influences satisfaction and loyalty in public transport? A review of the literature; Transport Reviews, 38: 52-72.

LUCAS, K. (2012): Transport and social exclusion: Where are we now? Transport Policy, 20: 105-113.

MÁLIKOVÁ, L. (2013): Theoretical and methodological aspects of identifying marginal rural areas in the Slovak and Czech studies. Zborník príspevkov medzinárodnej konferencie doktorandov. MendelNet (pp. 20-21). Brno, Mendelova univerzita v Brně.

MEES, P. (2010): Transport for suburbia: Beyond the automobile age. Earthscan Publishing.

MILAN, J. (1997): Comparison of the quality of rail and air networks in West, Central and Eastern Europe. Transport Policy, 4(2): 85-93.

MOUWEN, A. (2015): Drivers of customer satisfaction with public transport services. Transportation Research, Part A: Policy and Practice, 78: 1-20.

NASH, C. (1982): Economics of public transport. New York, Longman.

NASH, C. (2010): European rail reform and passenger services - the next steps. Research in Transportation Economics, 29(1): 204-211.

NELSON, J. D, SALEH, W., PRILESZKY, I. (1997): Ownership and control in the bus industry: The case of Hungary. Journal of Transport Geography, 5(2): 137-146.

NIELSEN, G., LANGE, T. (2007): Network Design for Public Transport Success - Theory and Examples. Thredbo 10 Conference, Australia.

NUTLEY, S. (2003):Indicators of transport and accessibility problems in rural Australia. Journal of Transport Geography, 11(1): 55-71.

PATMORE J.A. (1962): The changing network of British railways, Geography, 47(4): 401-405.

PEETERS, D., THISSE, J.F., THOMAS, I. (1998): Transportation networks and the location of human activities. Geographical Analysis, 30(4): 355-371.

PETERSEN, T. (2012): Public Transport for Exurban Settlements. Melbourne, University of Melbourne.

PETERSEN, T. (2016): Watching the Swiss: A network approach to rural and exurban public transport. Transport Policy, 52: 175-185.

PLAN ZAGOSPODAROWANIA PRZESTRZENNEGO WOJEWÓDZTWA DOLNOŚLASKIEGO, Perspektywa 2020, Urząd Marszałkowski Województwa Dolnośląskiego.

POŁOM, M., GOLISZEK, S. (2017): Transport in Poland during the period of accession to the European Union. Journal of Geography, Politics and Society 7(3): 41-49.

RODRIGUE, J. P., COMTOIS, C., SLACK, B. (2009): The geography of transport systems. Routledge.

ROSIK, P. (2012): Land accessibility of the Polish space at the European level. Geographical Works 233: Dostępność lądowa przestrzeni Polski w wymiarze europejskim. Prace Geograficzne 233.

SHARABY, N., SHIFTAN, Y. (2012): The impact of fare integration on travel behavior and transit ridership. Transport Policy, 21: 63-70. 
SHERGOLD, I., PARKHURST, G. (2012): Transportrelated social exclusion amongst older people in rural Southwest England and Wales. Journal of Rural Studies, 28(4): 412-421.

ŚLESZYŃSKI, P. (2014): Dostępność czasowa i jej zastosowania. Przegląd Geograficzny, 86(2): 171-215.

SMOLARSKI, M. (2017): Transport kolejowy w obsłudze gmin we wschodniej części pogranicza polsko-czeskiego. Prace Komisji Geografii Komunikacji PTG, 20: 78-90.

SMOLARSKI, M., JURKOWSKI, W. (2016): Aspekty organizacyjno-przestrzenne funkcjonowania prywatnej komunikacji autobusowej w Wałbrzychu. Transport Miejski i Regionalny, 1: 17-22.

SMOLARSKI, M., RACZYK, A. (2017): Przestrzenne zróżnicowanie wykluczenia komunikacyjnego w transporcie kolejowym na przykładzie województwa dolnośląskiego. Studia Miejskie, 27: 9-25.

SMOLARSKI, M., SUSZCZEWICZ, M. (2017): Wpływ niezależnego przewoźnika pasażerskiego (polskibus. com) na rynek przewozów międzywojewódzkich z miast średniej wielkości. Studia Miejskie, 23: 157-169.

ŠŤASTNÁ, M., VAISHAR, A. (2017): The relationship between public transport and the progressive development of rural areas. Land Use Policy, 67: 107-114.

ŠŤASTNÁ, M., VAISHAR, A., STONAWSKÁ, K. (2015): Integrated Transport System of the South-Moravian Region and its impact on rural development. Transportation Research, Part D: Transport and Environment, 36: 53-64.

STĘPNIAK, M., ROSIK, P., KOMORNICKI, T. (2013): Accessibility patterns: Poland case study. Europa XXI, 24: 77-93.

TACZANOWSKI, J. (2012): A comparative study of local railway networks in Poland and the Czech Republic. Bulletin of Geography. Socio-economic Series, 18: 125-139.

TAYLOR, Z. (1998): Polish transport policy: An evaluation of the 1994/5 White Paper. Journal of Transport Geography, 6(3): 227-236.

TAYLOR, Z. (2004): Recent changes in Polish transport policy. Transportation Reviews, 24(1): 19-32.

TAYLOR, Z. (2006): Railway closures to passenger traffic in Poland and their social consequences. Journal of Transport Geography, 14: 135-151.

TAYLOR, Z., CIECHAŃSKI, A. (2006): Deregulation in Polish rail transport. Transport Reviews, 26(3): 305-324.
TAYLOR,Z., CIECHAŃSKI, A. (2010): Niedawne przekształcenia organizacyjno-własnościowe przedsiębiorstw transportu kolejowego w Polsce - część I. Przegląd Geograficzny, 82(4): 549-571.

TAYLOR,Z.,CIECHAŃSKI,A.(2011):Niedawneprzekształcenia organizacyjno-własnościowe przedsiębiorstw transportu kolejowego w Polsce - część II. Przegląd Geograficzny, 83(2): 205-231.

TAYLOR, Z., CIECHAŃSKI, A. (2017): Deregulacja i przekształcenia własnościowe przedsiębiorstw transportu lądowego w Polsce na tle polityki spójności UE. Prace Geograficzne Nr. 257.Warszawa, PAN.

TAYLOR, Z., CIECHAŃSKI, A. (2018): Systemic transformation and changes in surface transport companies in Poland: A synthesis twenty years on. Journal of Transport Geography, 70: 114-122.

THÉVENIN, T., SCHWARTZ, R., SAPET, L. (2013): Mapping the Distortions in Time and Space: The French Railway Network 1830-1930. Historical Methods. A Journal of Quantitative and Interdisciplinary History, 46(3): 134-143.

TOMEŠ, Z., KVIZDA, M., NIGRIN, T., SEIDENGLANZ, D. (2014): Competition in the railway passenger market in the Czech Republic. Research in Transportation Economics, 48: 270-276.

VAISHAR, A. (2008): Possibilities for the multifunctional development of rural regions in the Czech Borderland. Europa XXI, 17: 63-70.

VELAGA， N. R., BEECROFT, M., NELSON， J. D., CORSAR, D., EDWARDS, P. (2012): Transport poverty meets the digital divide: accessibility and connectivity in rural communities. Journal of Transport Geography, 21: $102-112$.

WEGENER, M., KOMORNICKI, T., KORCELLI, P. (2005): Spatial impacts of the trans-European networks for the new EU Member States. Europa XXI, 13: 27-43.

WEINSTEIN, A. (2000): Customer satisfaction among transit riders: How customers rank the relative importance of various service attributes. Transportation Research Record: Journal of the Transportation Research Board, 1735: 123-132.

WIRASINGHE, S. C. (1980): Nearly optimal parameters for a rail/feeder-bus system on a rectangular grid. Transportation Research Part A: General, 14(1): 33-40.

\section{Please cite this article as:}

SMOLARSKI, M., JURKOWSKI, W., RACZYK, A. (2019): Bus and train connections between towns in Lower Silesia under different operational models: Competition or complementarity? Moravian Geographical Reports, 27(1): 31-40. Doi: 10.2478/mgr-2019-0003. 